\title{
POSTTRAUMATIC STRESS DISORDER (PTSD): MECHANISMS AND POSSIBLE TREATMENTS
}

\author{
Received June 18, 2014
}

Posttraumatic stress disorder (PTSD) is a debilitating mental condition occurring after a tragedy or a traumatic experience, such as rape, assault, natural disasters, war, car or plane accidents, etc. PSTD can cause a number of symptoms, such as fear, high anxiety, hyperarousal, bad dreams, night mares, etc., existing for a long time after the traumatic event. Within recent years, the spread of PTSD has been increased in the whole world, especially in Asia (Middle East), particularly among soldiers who have taken part in military conflicts. This situation confirms the importance of understanding the way of PTSD development and of the improvement of its treatment. This paper is a review of the literature related to the respective topics. Like other anxiety disorders, PTSD is related to disruption of the endocrine system, particularly disintegration of the hypothalamus-pituitary-adrenal axis (HPAA). People suffering from PTSD are characterized by elevated levels of corticotropinreleasing hormone, low basal cortisol levels, and enhanced negative feedback suppression of the HPAA. At present, certain plant-derived compounds are considered a new important source to treat PTSD. For example, remedies obtained from saffron are such possible means. According to our findings, saffron components may considerably affect some parts of the HPAA for reduction of stress-induced corticosterone release.

Keywords: posttraumatic stress disorder (PTSD), hypothalamo-pituitary (hypophyseal)adrenal axis (HPAA), corticosteroids, corticotropin-releasing hormone.

\section{INTRODUCTION}

Posttraumatic stress disorder (PTSD) is manifested as an aggregation of symptoms following exposure to extreme psychologically stressful or severe physically damaging events. This exposure can be visual or aural, and it can affect people who have been subjected to panic and desperation but avoided physical damage. Different events may lead to PTSD, such as car or plane accidents, criminal events, exposure to physical or sexual assaults [1], surviving from a disaster (e.g., flood or explosion) [2], or being the witness of the death of someone. In fact, all hard and horrifying events that can threaten life and safety, or events causing panic of not being secured, or repeated incidents are capable of

${ }^{1}$ Behavioral Sciences Research Center, Baqiyatallah University of Medical Sciences, Tehran, Iran

${ }^{2}$ Neuroscience Research Center, Baqiyatallah University of Medical Sciences, Tehran, Iran

Correspondence should be addressed to G. P. Jahromi (g_pirzad_jahromi@ yahoo.com) inducing this disorder. In some people, the respective emotional reactions continue for a long time, and this is the line by which healthy individuals and individuals having the risk of PTSD are separated.

In these individuals having bad memories related to a painful incident, unpleasant feeling of returning to the event can be brought to the mind by an occasional flux. Due to this reason, individuals with PTSD try to avoid all places or people who can remind the accidents; even talking about it would be avoided. These people have a sense of separation from the real world and do not show any interests towards the important activities within the social environment; they are nervous and irritable. A number of psychological and medical treatments have been proposed for patients with PTSD. In this review, we focused on the history of PTSD, on diagnosis of this disorder, and on its treatment. Special attention is paid to plant-derived remedies for the treatment of PTSD. 


\section{HISTORY}

In 1980, a term "PTSD" for the first time appeared in the system of classification of mental disorders. This does not mean that the above medical term was related to discovery of a new disease. As early as in 2000 BC, ancient Egyptians were aware of psychological symptoms of post-war mental shifts. Also, ancient Greeks observed and described a disturbance similar to PTSD among soldiers after the battle of Marathon in year 450 BC [3]. In 1975, with the end of the Vietnam War, the symptoms of fear, panic, and constant high anxiety among American soldiers, who survived the battle and returned to their homes, were frequently observed. Recently, more than 30 years after the Vietnam War, a study conducted on the veterans of this war showed that long-term posttraumatic stress causes not only a mental suffering; it creates a serious risk of physical illnesses and quick death. Statistical examinations showed that $7-8 \%$ of the general population suffered from PTSD symptoms during their period of life [4-6]. In Iran medical records, it has been demonstrated that more than $80 \%$ of war veterans are more or less prone to PTSD symptoms [7]. Common mental health problems have been reported among people who were often at the frontline of the battle [8].

\section{RECOGNITION}

Clinical features of PTSD are the most painful feelings that the incidents may happen again, and the problems may exist for months and even years although the event will not occur again. On physical examinations, the patients often feel guilty, rejected, and humiliated; sometimes perceptual errors and illusions are observed. In cognitive testing, the patients may demonstrate impaired memory and attention, and these phenomena could mostly be attributed to the increase in the adrenalin level. As is generally known, this hormone is produced be adrenals under stress conditions, and its release provides physical fitness for a rapid response in the case of danger; when stress is removed, this index should fall. In PTSD, memory recalls of the incident raise the adrenalin level, which can cause secondary stress, restlessness, and insomnia [9].

The hippocampus is a part of the CNS mostly responsible for processing memories. High levels of the hormones (adrenalin in particular) released during stress may disturb normal functioning of the hippocampus. This means that memories of traumatic events and nightmares will be continued and cannot be processed correctly. If the stress is removed, and the adrenalin level returns to the norm, the brain will be able to repair the damage; bad memories will be processed and adequately recognized, and nightmares and other symptoms will be lost. Posttraumatic disorders typically associated with changes induced by intense acute or chronic stress are frequently placed in the group of anxiety disorders as a mental illness [10].

PTSD, like other anxiety disorders, occurs, to a significant extent, as a result of dysfunction of the neuroendocrine mechanisms and endocrine system. That mostly "followed the disintegration of the hypothalamo-pituitary axis and adrenals per se" [1, $11,12]$. According to endocrinological studies, three common features have been reported in patients suffering from PTSD. These are: (i) reduction in the plasma cortisol level, (ii) increase in the level of corticotropin-releasing hormone $(\mathrm{CRH})$ in the cerebrospinal fluid (CSF) and plasma, and (iii) increased inhibition of the hypophyseal (pituitary)adrenal system (HAS) through a negative feedback. Therefore, the clinical pattern of PTSD is a paradox from the endocrinilogical point of view because increased activity of the hypothalamo-pituitaryadrenal axis (HPAA) is a central component associated with stress. At the same time, an insufficient level of pituitary-adrenal (HAS) activity should be considered a crucial shift in the regulatory endocrinological influences observed in PTSD patients.

The mechanism of the emergence of this disease has not been studied adequately. It is known, however, that patients with anxiety disorders demonstrate either low or normal cortisol levels in the blood [13, 14], high CRH levels in the CSF and plasma [15, 16], as well as enhanced inhibition of the pituitaryadrenocortical system realized via negative feedback $[12,17]$. High CRH combined with high vasopressin in neurosecretory cells and nerve terminals in the hypothalamus is created under stress condition, and this intensifies the synthesis and secretion of ACTH from the pituitary, as well as those of a releasing hormone, corticoliberin [18, 19].

In terms of the prognosis, it is noteworthy that the PTSD symptoms may significantly fluctuate over time. The severity of symptoms is the greatest during periods of high stress; about $30 \%$ of patients completely recover, while about $10 \%$ demonstrate no improvement of worsening of the symptoms. 
Generally, according to DSM4, when the disease is diagnosed until 4 weeks after the event and continues from 2 days to 4 weeks, it is called a reparable disorder. However, when acute psychiatric and remaining symptoms are observed during more than 4 weeks, PTSD is diagnosed with certainty. Generally, when a person has been exposed to a stressful event and regularly recalls this incident in mind during more than one month, he/she may show the following symptoms: (i) restlessness and agitation, aggressive behavior, feelings of alienation from others; (ii) isolation and difficulties in interpersonal relationship; (iii) guilt and shame, careless and emotional poverty that makes them stay away from the others; (iv) a developmental regression procedure, return to basic behaviors of a child (e.g., thumb sucking, etc.); (v) excessive emotional and behavioral arousal (constant state of alert); (vi) sleep disturbances, nightmares, and scary dreams (frightening dreams without a specific content); (vii) avoidance of thoughts and feelings, avoidance of places that remind unpleasant events; (viii) repeated memories on the traumatizing events; (ix) repeated games related to the traumatic experience (in children), and (x) interference with daily work, difficulties in concentration and learning $[20,21]$.

\section{PATHOGENESIS OF PTSD}

Neuroanatomy. At present, three areas in the brain have been identified, which may change during PTSD; these are the prefrontal cortex, amygdalar complex, and hippocampus. Many respective studies have been carried out on patients of the Vietnam War. For example, observations of soldiers with injured heads revealed that the prefrontal cortex plays an important role in the prevention or development of PTSD symptoms. In human studies, the amygdale has shown to be strongly involved in the formation of emotional memories, especially fear-related ones. Neuroimaging studies in humans revealed both morphological and functional aspects of changes in the above cerebral structures related to PTSD [22]. It was found that the hippocampus, i.e., the structure specifically associated with the ability to place memories within the correct spatial/temporal context and with the ability to recall memories, is suppressed during intense stress [23]. Koenen et al. [9] showed that the state of the hippocampus exerts a strong influence on PTSD. Veterans of the Vietnam War with PTSD showed a $20 \%$ reduction in the volume of their hippocampus compared with the veterans who did not suffer from such symptoms. Therefore, it is thought that inhibition of the hippocampal functions related to partial degeneration of hippocampal neuronal circuits during severe stress determines obsessive reminding of the incident occurred in patients with PTSD [12, 24]. As was mentioned, persistent fear in patients with PTSD could be due to impairments of the HPAA, noradrenergic system of the locus coeruleus, and connections between the limbic system and frontal cortex. The HPAA is a coordinator of the hormonal response under stress conditions. If the event is traumatic, the HPAA is stimulated, and activation of the noradrenergic locus coeruleus system consequently leads to a physiologically excessive increase in the strength of memory consolidation on the event. Thus, PTSD patients regularly remind the time and place of the event bleak picture.

It seems that the noradrenergic locus coeruleus system plays an important role in increasing the power of memory consolidation due to stress. Studies on animal models have shown that neuropeptide $\mathrm{Y}$ reduces the secretion of norepinephrine (noradrenalin), and this plays an important role in reducing the anxiety level in patients with PTSD. Human studies showed that concentrations on neuropeptide $\mathrm{Y}$ are reduced in patients suffering from this disorder [25].

Roles of Hormones in Creating PTSD. PTSD symptoms appear when stress causes a severe increase in the secretion of adrenalin (epinephrine) in circulation. High concentration of adrenalin causes significant neurochemical and neurophysiological changes in the brain. These shifts may remain for a long time and maintain a sense of fear in the person. High levels of stress hormones suppress the functions of the hypothalamus, and this is an important factor in the occurrence of PTSD symptoms. This disorder can cause a series of considerable biochemical changes in the brain and in the entire body, which differ from those in other psychological disorders, such as different types of depression. The responses of patients with PTSD to the dexamethasone test are much more intense than those in patients with a depression disorder. In addition, patients with such dexamethasone test pattern often demonstrate lower concentrations of cortisol and higher concentrations of catecholamines in their urine than other depressed patients. Also, the norepinephrine/cortisol ratio in patients with PTSD is much higher than that in "usual" depressed patients. These changes occurring in subjects with PTSD significantly differ from those observed under 
conditions of the fight-or-flight response in people faced the stress, where concentrations of both cortisol and catecholamines increase in a parallel manner. Patients with PTSD demonstrate increased levels of $\mathrm{CRH}$ and cerebral catecholamines, which is indicative of a considerable disorder of the HPAA function. This axis is responsible for coordination of the hormonal responses to stress. It seems that, due to the increased sensitivity of glucocorticoid receptors in patients with PTSD, impairment of the HPAA and negative feedback inhibition results in a reduced cortisol concentration. Thus, because of increased sensitivity of the HPAA in patients with PTSD. Non-adaptive learning paths can be formed due to the increase of fear. Thus, it is likely that the levels of cortisol should be precisely considered to be a significant factor leading to symptoms of PTSD. It was found that war veterans having lower concentrations of cortisol in their saliva than other soldiers with normal cortisol levels were more susceptible to PTSD. Because cortisol plays an important role in the general maintenance of homeostasis, disorders in the latter during stress in patients with PTSD may lead to persistent feelings of fear in them. Other studies have shown that serotonin levels are relatively low (frequently abnormally) in PTSD patients. As is known, the serotonergic system is involved in the formation of mood, anxiety, aggression, and irritability; it also provides stabilization of the secretion of glucocorticoids [26, 27].

Similarly to $\mathrm{CRH}$, vasopressin plays a role in the stress responses and acts synergistically with the above releasing hormone [28, 29]. Both above hormones are produced in neurosecretory cells of the hypothalamus and exert strengthening effects on the synthesis and secretion of ACTH from the pituitary and release of the latter hormone in stressful situations $[18,19]$. CRH produced by neurons in the paraventricular nucleus (PVN) of the hypothalamus is involved in neuroendocrine control of ACTH secretion from the pituitary anterior lobe. Also, $\mathrm{CRH}$ enhances the activity of the sympathetic nervous system. Increases in the release of vasopressin and CRF start an endocrine response to the stressful situation and ultimately stimulate the release of proopiomelanocortin (POMC), ACTH, and beta-endorphin. ACTH is a key moderator of glucocorticoid secretion from the adrenal cortex. Glucocorticoids, particularly cortisol in humans and corticosterone in rats, act as the main effect of HPAA activation in the control of body homeostasis in response to stress. As it was reported, patients with PTSD, due to high baseline levels of CRH in the CSF and plasma, react to intravenous injections of CRH by slow secretory ACTH responses from the pituitary. Because of the continued presence of high concentrations of anterior pituitary $\mathrm{CRH}$, receptors of the latter undergo desensitization, and the abovementioned responses are reduced [30-32]. According to the results of the dexamethasone suppression test, another treatment has been proposed within recent years. This test is used to measure dexamethasoneinduced inhibition of the HPAA [30].

It should be noted that there are conflicting opinions in neurobiology of PTSD. For example, some studies have shown that there is no clear relationship between the blood cortisol levels and PTSD symptoms. At the same time, most studies of the major causes of PTSD symptoms demonstrated that increased concentrations of $\mathrm{CRH}$, decreases blood cortisol levels, and increased negative feedback suppression of the HPAA are the main correlates of this mental disorder.

\section{APPROACHES TO PTSD TREATMENT}

Psychological Techniques. Based on the abovementioned data and considering the aim of improving mental and physical health of the patients, researchers focused their attention on both physical and psychological aspects of the disease and proposed psychological and physical therapy for PTSD treatment. In particular, the National Institute for Health and Care Excellence (NICE) suggested traumafocused psychological therapy (Cognitive Behavioral Therapy, CBT) or an Eye Movement Desensitization Reprocessing (EDMR) technique before specific medication can be used.

Two psychotherapeutic approaches for treating PTSD patients have been proposed; these approaches are based on different general concepts, cognitive psychology and behaviorism. Behavioral interventions may include learning of how effectively confront fears and avoid places or people that could remind stressinducing events. The use of sedation techniques and accepting the feelings of the patient are effective in reducing the symptoms of posttraumatic stress.

A crisis intervention technique is based on attempts to restore normal mental functions of the patients. Psychiatrists are focused on the methods allowing patients to solve problems related to coping skills and to create a supportive environment for the patient. It was also found expedient to form a support group 
for people who are experiencing stress symptoms. Members of these groups of patients receive the emotional support from others who have experienced similar symptoms and conditions; they also learn coping skills and how to manage the conditions. All these treatments must be led and performed by a specialist having the sufficient experience in the treatment of PTSD. These meetings should be carried out by an expert during at least 8 to 12 weeks; each session takes 60 to $90 \mathrm{~min}$ [33].

Cognitive behavioral therapy (CBT) is another treatment method that helps patients to think differently about bad memories. Therefore, the subjects become less stress-affected and more manageable. Usually, this treatment includes multiple sessions (with relaxation) that help patients "to feel pleasant to think about unpleasant events." An eye movement desensitization and reprocessing (EMDR) technique uses recording of eye movements to help the brain to process unpleasant incidents. This technique seems somewhat strange, but the respective treatment was found to be rather effective.

Psychological therapies are usually ineffective if PTSD symptoms continue for more than a month. In other cases, impaired functions, such as inadequate performance of the patient's job, etc, need transition toward drug treatments. Although PTSD should be considered an independent risk form for health, combined bad habits can threaten the patient's health. For example, $45 \%$ of people with PTSD are smokers; some of these patients, when trying to escape from emotional problems, tend to use alcohol and drugs [34].

Treatment of PTSD with Natural Herbal Products. Effects of medical plants and their derivatives in the treatment of various diseases are studied more and more extensively within recent years. These studies have shown that a number of medicinal herbs demonstrate comparable (or even greater) efficiency in the respective cases than "traditional," "standard" pharmacological agents. At the same time, there are very few studies of applications of medicinal plants for the treatment of PTSD. We concentrated our attention to such a plant as saffron and shall try to describe the respective results in more detail.

Saffron, Crocus sativus L. (Iridaceae) is a plant known from ancient times, which has been used during centuries as a food ingredient (spice). It is also known in folk medicine as an antispasmodic, expectorant, and even as aphrodisiac. Saffron has a bitter taste mostly due to the presence of a component called picrocrocin.
This compound can be converted by thermal decomposition or fermentation to aromatic aldehydes, saffronil, in particular. Saffron components, such as crocin, are glycosides consisting of a carotenoid called crocitin (which is responsible for the color of saffron) and sugar. The main physiologically active ingredients of saffron are safronal, crocin, and crocetin $[35,36]$.

Saffron has been demonstrated to be rather highly efficient with respect to neurological abnormalities. For example, saffron was effective in reducing symptoms of depression and anxiety. These effects in humans were comparable with those of imipramine and fluoxetine. The effects of the saffron extract were checked out on experiments on mice and demonstrated a high efficiency in reducing the anxiety level [37]. An inhibitory effect of this herb in reducing symptoms of anxiety and dependence of morphine in the conditioned place preference test were shown [38]. Previous studies demonstrated that the saffron extract and its active components (safronal) improve brain functions (through inhibition of serotonin reuptake and stimulation of GABA receptors) in some pathologies, such as Alzheimer disease, epilepsy, and other seizure disorders in humans [39]. Sahraei et al. [40] described positive effects of the aqueous saffron extract and safronal, which improved mental and physical symptoms of stress and those related to PTSD. The effects were clearly dose-dependent. In this study, the animals, 21 days after termination of a stress-induced disorder, were exposed to environmental stress for the second time. Groups that received the saffron extract or safronal did not show significant disorders, while the control groups demonstrated strong hormonal effects and also strong anorexia. It could be supposed that saffron derivatives influence the inner core of the amygdale (basolateral nuclei). At the same time, the saffron extract and safronal exerted no effects on behaviors associated with the dopaminergic system, such as exploratory movements. Finally, it was concluded that, on the one hand, a positive effect of the extract (moderation of stress-related symptoms) was clearly present. On the other hand, the efficacy of the saffron extract with respect to the basal ganglia of the amygdale was lacking. It should be supposed that the respective compounds of the aqueous extract of saffron probably reduced corticosteron secretion and inhibited anorexia. Thus, the effects on the adrenal cortex and hypothalamus should be considered [40, 41]. The saffron extract may realize some of its effects by blocking glutamate receptors and by increasing concentrations of glutamate and dopamine in the 
rat brain. These neurotransmitters are involved in facilitation of memory-related cerebral phenomena and facilitation of release of the hormones from the hypothalamus. It seems that the release of these two neurotransmitters is altered under stress conditions in line with the release of corticosterone and memory reinforcement $[42,43]$. In another study, Halataei et al. [44] showed that the saffron aqueous extract much stronger affected metabolic responses in electric shock-induced stress (release of corticosteroids, anorexia, and weight loss in animals) than the ethanol extract of saffron did. This effect is mediated by the amygdalar complex [45] and hypothalamus [46].

It was shown that there is a close overlap between the effects of stress and addictive drugs [47-49]; this was demonstrated on animal models. Moffet et al. in 2006 [50] highlighted stress phenomena induced by maternal separation in young rats; it was shown that this situation intensifies self-administration of cocaine. On the other hand, it was shown in human studies that prenatal stress tends to cause high probabilities of smoking, using of marihuana, consumption of alcohol, and using amphetamines in adulthood [51]. In another study, Sahraei et al. [40] showed the ability of saffron to provide inhibitory effects on the mesocorticolimbic system. So, saffron helps to improve the state of people suffering from defective functioning of this system. At the same time, this mean (or a group of means) does not have side effects of addictive drugs. Thus, consumption of saffron-based means is prospective with respect to the reduction of physiological symptoms of stress in people involved in a stressful job and other stress-inducing situations [40].

\section{CONCLUSIONS}

The above-described data demonstrate the importance of adequate functioning of the HPAA and the state of the respective neuroendocrine and hormonal systems under stress and post-stress conditions. Thus, compounds capable of normalizing the control of production of the hormones secreted by the above axis, such as corticosterone and cortisol, are likely to have the ability to reduce PTSD symptoms. Today, great attention is paid to the use of "non-chemical" treatments, such as herb-based means, to cure the above-described pathologies. It is obvious that further studies are urgently necessary to understand the mechanisms of plant-derived agents and their possible role in modifying the control in multiple-organ systems. Saffron is an example of the plants that could be effectively applied in the treatment of PTSD and disorders close to the latter. The compounds contained in this plant can help to normalize regulation of corticosterone release and the state of the respective central neuronal mechanisms, which allow one to reduce PTSD symptoms in the respective patient contingent with minimum induction of side effects.

This paper is a review of the published data, and confirmation of its correspondence to the ethical norms for experiments on animals and/or studies of humans is no necessary.

The authors, S. Asalgoo, G. P. Jahromi, G. H. Meftahi, and H. Sahraei, confirm that they have no conflict of interest with any organization or person that may be related to this study; there were also no conflict of interest in interrelations between the authors.

\section{А. Асалгоо ${ }^{1}$ Г. П. Яхромі ${ }^{1}$ Г. Х. Мефтахі ${ }^{1}$, Х. Сахрей ${ }^{1}$}

ПОСТТРАВМАТИЧНИЙ СТРЕС-РОЗЛАД (ПТСР): МЕХАНІЗМИ ТА МОЖЛИВІ МЕТОДИ ЛІКУВАННЯ

${ }^{1}$ Центр досліджень у сфері нейронаук Медичного університету Бакійаталлах, Тегеран (Іран).

Р е з ю м е

Посттравматичний стрес-розлад (ПТСР) є психіатричною патологією, що розвивається після трагічної або травматизуючої події - смерті/убивства, згвалтування, природних катастроф, воєнних дій, автомобільних або авіаційних аварій. ПТСР може бути пов'язаний з багатьма симптомами - жахом, сильною тривогою, надмірним збудженням, негативними думками, нічними кошмарами, прояви котрих тривають протягом значного часу після травматизуючої події. Впродовж останніх років розповсюдження випадків ПТСР у світі, особливо на Середньому Сході та в Азії, збільшилося, зокрема серед солдатів, що брали участь у воєнних діях. Така ситуація підкреслює важливість розуміння того, як розвивається ПТСР, та розробки підходів до його лікування. Наша стаття є оглядом даних літератури щодо відповідного кола питань. Як і інші розлади, пов'язані з тривожністю, ПТСР значною мірою базується на дисфункції ендокринної системи, зокрема на дезінтеграції гіпоталамо-гіпофізарно-адреналової осі (ГГАО). Для людей із ПТСР є характерними високі рівні кортикотропін-рілізінг-гормону, низькі базальні рівні кортизолу та посилена супресія функції ГГАО на основі негативного зворотного зв'язку. В наш час певні препарати рослинного походження розглядаються як важливі засоби для лікування ПТСР. Зокрема, такими ліками можуть бути препарати, отримані із шапрану. Згідно з нашими даними, речовини, що містяться в шапрані, взаємодіють із деякими 
ГГАО та забезпечують зменшення вивільнення кортикостерону, індукованого стресом.

\section{REFERENCES}

1. D. G. Kilpatrick, C. Edmunds, and A. Seymour, Rape in America: A Report to the Nation. National Victim Center and the Crime Victims Research and Treatment Center, Med. Univ. South Carolina, Charleston (1992).

2. P. B. John, S. Russell, and P. S. Russell, "The prevalence of posttraumatic stress disorder among children and adolescents affected by tsunami disaster in Tamil Nadu," Disaster Manag. Resp., 5, No. 1, 3-7 (2007).

3. M. H. Swartz, Textbook of Physical Diagnosis: History and Examination, Saunders Elsevier (2006).

4. G. C. Gray, K. S. Kaiser, A. W. Hawksworth, et al., "Increased postwar symptoms and psychological morbidity among U.S. Navy Gulf War veterans,"Am. J. Trop. Med. Hyg., 60, No. 5, 758-766 (1999).

5. T. M. Keane, A. D. Marshall, and C. T. Taft, "Posttraumatic stress disorder: Etiology, epidemiology, and treatment outcome," Annu. Rev. Clin. Psychol., 2, 161-197 (2006).

6. R. C. Kessler, A. Sonnega, E. Bromet, et al., "Posttraumatic stress disorder in the National Comorbidity Survey," Arch. Gen. Psychiat., 52, No. 12, 1048-1060 (1995).

7. A. Bahreinian and H. Borhani, "Mental health in group of war veterans and their spouses in Qom," Quart. J. School Med., 27, No. 4, 305-312 (2003).

8. M. Mendenhall, Chaplains in Mental Health: Healing the Spiritual Wounds of War (Cover Story), Am. Psychother. Ass., Springfield (2010).

9. K. C. Koenen, S. D Stellman, J. F Sommer Jr., and J. M. Stellman, "Persisting posttraumatic stress disorder symptoms and their relationship to functioning in Vietnam veterans: A 14-year follow-up," J. Trauma Stress, 21, No. 1, 49-57 (2008).

10. G. Meftahi, Z. Ghotbedin, M. J. Eslamizade, et al., "Suppressive effects of resveratrol treatment on the intrinsic evoked excitability of CA1 pyramidal neurons," Cell J. (Yakhteh), 17, No. 3, (2015).

11. M. Olff, Y. Güzelcan, G. J. de Vries, et al., "HPA- and HPTaxis alterations in chronic posttraumatic stress disorder," Psychoneuroendocrinology, 31, No. 10, 1220-1230 (2006).

12. R. Yehuda, "Advances in understanding neuroendocrine alterations in PTSD and their therapeutic implications," Ann. New York Acad. Sci., 1071, 137-156 (2006).

13. D. Simeon, M. Knutelska, R. Yehuda, et al., "Hypothalamicpituitary-adrenal axis function in dissociative disorders, post-traumatic stress disorder, and healthy volunteers," Biol. Psychiat., 61, No. 8, 966-973 (2007).

14. M. A. Oquendo, G. Echavarria, H. C. Galfalvy, et al., "Lower cortisol levels in depressed patients with comorbid posttraumatic stress disorder," Neuropsychopharmacology, 28, No. 3, 591-598 (2003).

15. C. S. de Kloet, E. Vermetten, E. Geuze, et al., "Elevated plasma corticotrophin-releasing hormone levels in veterans with posttraumatic stress disorder," Prog. Brain Res., 167, 281-291 (2007).

16. V. M. Voloshin, PTSD, Phenomenology, Clinical Aspects Systematics, Dynamics, and Contemporary Approaches to
Psychopharmacotherapy [in Russian], Anakharsis, Moscow (2005).

17. C. S. de Kloet, E. Vermetten, C. J. Heijnen, et al., "Enhanced cortisol suppression in response to dexamethasone administration in traumatized veterans with and without posttraumatic stress disorder," Psychoneuroendocrinology, 32, No. 3, 215-226 (2007).

18. A. J. Douglas, N. H. Steckler, and N. H. Kalin, "Vasopressin and Oxytocin," in: Handbook of Stress and the Brain, The Neurobiology of Stress, Elsevier, Amsterdam, (2005) pp. 205230.

19. M. V. Ugryumov, Mechanisms of Neuroendocrine Regulation [in Russian], Nauka, Moscow (1999).

20. P. Ouimette, D. Coolhart, D. Sugarman, et al., “A pilot study of posttraumatic stress and associated functioning of Army National Guard following exposure to Iraq warzone trauma," Traumatology, 14, No. 3, 51-56 (2008).

21. I. M. Engelhard, M. A. van den Hout, J. Weerts, et al., "Deployment-related stress and trauma in Dutch soldiers returning from Iraq. Prospective study," Br. J. Psychiat., 191, 140-145 (2007).

22. D. J. Newport and C. B. Nemeroff, "Neurobiology of posttraumatic stress disorder," Current Opin. Neurobiol., 10, No. 2, 211-218 (2000).

23. D. L. Schacter, D. T. Gilbert, D. M. Wegner, et al., Introducing Psychology, Worth Publ., New York (2011).

24. M. J. Eslamizadeh, F. Saffarzadeh, S. M. Mousavi, et al., "Alterations in CA1 pyramidal neuronal intrinsic excitability mediated by Ih channel currents in a rat model of amyloid beta pathology," Neuroscience, 305, 279-292 (2015).

25. K. Skelton, K. J. Ressler, S. D. Norrholm, et al., "PTSD and gene variants: New pathways and new thinking," Neuropharmacology, 62, No. 2, 628-637 (2012).

26. J. Zohar, A. Juven-Wetzler, V. Myers, and L. Fostick, "Posttraumatic stress disorder: Facts and fiction," Current Opin. Psychiat., 21, No. 1, 74-77 (2008).

27. R. Yehuda, S. L. Halligan, J. A. Golier, et al., "Effects of trauma exposure on the cortisol response to dexamethasone administration in PTSD and major depressive disorder", Psychoneuroendocrinology, 29 (3), 389-404 (2004).

28. E. B. De Souza and D. E. Grigoriadis, "Corticotropinreleasing factor: physiology, pharmacology, and role in central nervous system and immune disorders", Am. Coll. Neuropsychopharmacol., Chapt. 7, 91-107 (2002).

29. V. G. Shalyapina, "Corticoliberin in the regulation of adaptive behavior in the pathogenesis of post-stress depression," in: Basic Neuroendocrinology [in Russian], ÉLBI, St. Petersburg (2005), pp. 84-146.

30. C. S. de Kloet, E. Vermetten, E. Geuze, et al., “Assessment of HPA-axis function in posttraumatic stress disorder: Pharmacological and non-pharmacological challenge tests, a review," J. Psychiat. Res., 40, No. 6, 550-567 (2006).

31. F. M. Dautzenberg, S. Braun, and R. L. Hauger, "GRK3 mediates desensitization of CRF1 receptors: a potential mechanism regulating stress adaptation," Am. J. Physiol. Regulat. Integr. Comp. Physiol., 280, No. 4, 935-946 (2001).

32. M. Salehi, H. Eimani, H. Sahraei, and G. H. Meftahi, "Stress can changes reward system function in second-generation (F2): a review," Adv. Biores., 6, No. 5, 4-14 (2015).

33. J. C. Shipherd, A. E. Street, and P. A. Resick, "Cognitive therapy for posttraumatic stress disorder," in: CognitiveBehavioral Therapies for Trauma, Guilford Press, New York 
(2006), pp. 96-116.

34. J. Bisson and M. Andrew, "Psychological treatment of posttraumatic stress disorder (PTSD)," Cochrane Database Syst. Rev., No. 3, CD003388 (2007).

35. M. Ghodrat, H. Sahraei, J. Razjouyan, and G. H. Meftahi, "Effects of a saffron alcoholic extract on visual short-term memory in humans: a psychophysical study," Neurophysiology, 46, No. 3, 247-253 (2014).

36. S. K. Verma and A. Bordia, "Antioxidant property of Saffron in man," Ind. J. Med. Sci., 52, No. 5, 205-207 (1998).

37. H. Yaribeygi, H. Sahraei, A. R. Mohammadi, and G. H. Meftahi, "Saffron (Crocus sativus L.) and morphine dependence: A systematic review article," Am. J. Biol. Life Sci., 2, No. 2, 41-45 (2014).

38. H. Sahraei, J. Shams, S. Marjani, et al., "Effects of the Crocus sativus L. Extract on the acquisition and expression of morphine-induced behavioral sensitization in female mice," J. Med. Plants, 6, No. 21, 26-35 (2007).

39. S. Soeda, T. Ochiai, L. Paopong, et al., "Crocin suppresses tumor necrosis factor- $\alpha$-induced cell death of neuronally differentiated PC-12 cells," Life Sci., 69, No. 24, 28872898 (2001).

40. H. Sahraei, Z. Fatahi, A. H. Rohani, et al., "Ethanolic extract of saffron and its constituent crocin diminish stressinduced metabolic signs and alterations of dopaminerelated behaviours in rats," Int. Res. J. Pharm. Pharmacol., 2, No. 7, 165-173 (2012).

41. H. Sahraei, Z. Fatahi, A. Eidi, et al., "Inhibiting post traumatic stress disorder (PTSD) induced by electric shock using ethanol extract of saffron in rats," J. Biol. Res. Thessalon, 18, 320-327 (2012).

42. K. Abe and H. Saito, "Effects of saffron extract and its constituent crocin on learning behavior and long-term potentiation," Phytother. Res., 14, No. 3, 149-152 (2000).
43. G. H. Meftahi, M. Janahmadi, and M. J. Eslamizade, "Effects of resveratrol on intrinsic neuronal properties of CA1 pyramidal neurons in rat hippocampal slices," Physiol. Pharmacol., 18, No. 2, 144-155 (2014).

44. B. A. Halataei, M. Khosravi, S. Arbabian, et al., "Saffron (Crocus sativus) aqueous extract and its constituent crocin reduces stress-induced anorexia in mice," Phytother. Res., 25, No. 12, 1833-1838 (2011).

45. D. B. Miller and J. P. O'Callaghan, "Neuroendocrine aspects of the response to stress," Metabolism, 51, 6 Suppl., 5-10 (2002).

46. T. C. Adam and E. S. Epel, "Stress, eating and the reward system," Physiol. Behav., 91, No. 4, 449-458 (2007).

47. M. Erfani, H. Sahraei, and G. H. Meftahi, "Study of the effects of maternal psychological and physical stress on morphine-induced tolerance in F2 NMRI generation mice," $A d v$. Biores, 6, No. 6, 134-140 (2015).

48. D. Chalabi-Yani, H. Sahraei, G. H. Meftahi, et al, "Effect of transient inactivation of ventral tegmental area on the expression and acquisition of nicotine-induced conditioned place preference in rats," Iran. Biomed. J., 19, No. 4, 214-219 (2015).

49. S. B. Hosseini, H. Sahraei, A. Mohammadi, et al., "Inactivation of the nucl. accumbens core exerts no effect on nicotineinduced conditioned place preference," Neurophysiology, 47, No. 4, 295-301 (2015).

50. M. C. Moffett, J. Harley, D. Francis, et al., "Maternal separation and handling affects cocaine self-administration in both the treated pups as adults and the dams," J. Pharmacol. Exp. Ther., 317, No. 3, 1210-1218 (2003).

51. A. McFarlane, C. R. Clark, R. A. Bryant, et al., "The impact of early life stress on psychophysiological, personality and behavior measures in 740 non-clinic subjects," J. Integr. Neurosci., 4, No. 1, 27-40 (2005). 